\title{
Aktivitas Enzim Ekstraseluler dari Bakteri Endofit Tumbuhan Mangrove Avicennia marina
}

\section{Extracellular Enzymatic Activities of Endophytic Bacteria of the Mangrove Plant Avicennia marina}

\author{
Chindy Achika Rori*, Febby Ester Fany Kandou, Agustina Monalisa Tangapo \\ Jurusan Biologi FMIPA UNSRAT Manado \\ *E-mail:rorichindy99@gmail.com
}

(Article History: Received 1 Mei 2020; Revised 15 Mei 2020; Accepted 27 Mei 2020)

\begin{abstract}
ABSTRAK
Bakteri endofit merupakan salah satu sumber penghasil senyawa ekstraseluler yaitu enzim. Enzim dari bakteri endofit lebih menguntungkan dan produksinya lebih cepat. Penelitian ini bertujuan untuk menganalisis kemampuan aktivitas enzim ekstraseluler dari bakteri endofit tumbuhan mangrove Avicennia marina. Metode penelitian yang digunakan yaitu eksploratif eksperimental, melakukan isolasi bakteri dari tumbuhan mangrove A. marina dan selanjutnya dilakukan uji potensi aktivitas enzim ekstraseluler dari isolat bakteri endofit. Hasil isolasi memperoleh tujuh isolat bakteri endofit dari tumbuhan A. marina, isolat endofit tersebut mampu menghasilkan aktivitas enzim ekstraseluler yaitu empat isolat menghasilkan enzim amilase, enam isolat menghasilkan protease, satu isolat menghasilkan selulase dan dua isolat menghasilkan gelatinase.

Kata kunci: bakteri endofit; Avicennia marina; amilase; protease; selulase; gelatinase
\end{abstract}

\section{ABSTRACT}

Endophytic bacteria are one source that can produce extracellular compounds, namely enzymes. Enzymes from endophytic bacteria are more profitable and can produce faster. This study aims to analyze the ability of extracellular enzyme activity from endophytic bacteria in mangrove plants Avicennia marina. This research used experimental explorative method, isolating bacteria from mangrove plant A. marina and then testing the potential of enzyme extracellular activity from endophytic bacteria isolated. Isolating result obtained seven endophytic bacterial isolates from A. marina plants,this endophytic isolates are able to produce extracellular enzyme activity is four isolates can produced amylase enzyme, six isolated can produced protease, one isolated can produced cellulase and two isolated can produce gelatinase.

Keywords: Endophytic bacteria; Avicennia marina; amylase, protease, cellulase, gelatinase

\section{PENDAHULUAN}

Endofit merupakan mikroorganisme yang menghabiskan seluruh atau sebagian dari siklus hidupnya di dalam tanaman dan tidak menyebabkan gejala tertentu pada tanaman inangnya tersebut (Hallman et al. 1997). Komunitas endofit memberikan keuntungan terhadap tanaman inangnya seperti melindungi tanaman melawan herbivora, serangga, atau patogen, serta mampu menstimulasi pertumbuhan tanaman. Berbagai penelitian tentang komunitas bakteri yang berasosiasi dengan tanaman sebagai endofit telah berkembang cukup pesat mengingat pentingnya kontribusi komunitas bakteri tersebut. Salah satunya kontribusi dari bakteri endofit yaitu sebagai penghasil enzim. Enzim dari mikroorganisme lebih menguntungkan dan produksinya lebih cepat dibandingkan enzim yang berasal dari tanaman dan hewan. Melliawati et al. (2012) memperoleh 86 isolat bakteri endofit penghasil protease yang berasal dari Taman Nasional Gunung Halimun. Bakteri merupakan salah satu mikroorganisme yang unggul dalam usaha produksi enzim (Pricilia et al. 2018).

Berdasarkan kemampuan bakteri endofit yang sangat besar dan keanekaragaman hayati yang ada di Indonesia ini menjadikan prospek penelitian tentang bakteri endofit dari tumbuhan yang ada di Indonesia sangat besar. Kawasan mangrove merupakan ekosistem utama pendukung kehidupan yang 
penting di wilayah pesisir dan lautan. Banyak manfaat yang dapat diambil dari tumbuhan mangrove (Saprudin dan Halida, 2012). Salah satunya yaitu mikroorganisme yang berasosiasi dengan mangrove.

Ekosistem mangrove memiliki keanekaragaman hayati yang tinggi. Avicennia marina merupakan salah satu spesies mangrove yang sangat penting. Sampai saat ini, belum ada laporan penelitian tentang bakteri endofit A. marina yang ada di sekitar Kota Manado. Mengingat potensinya sebagai tanaman mangrove yang hidup di daerah tropis sangat besar, maka penelitian tentang bakteri endofit $A$. marina sebagai penghasil enzim ekstraseluler penting untuk dilakukan. Penelitian ini bertujuan untuk menganalisis dan mengeksplorasi kemampuan aktivitas enzim ekstraseluler dari bakteri endofit tumbuhan mangrove A. marina.

\section{METODE}

Metode yang digunakan dalam penelitian ini yaitu deskriptif eksploratif yaitu dengan melakukan isolasi bakteri dari tumbuhan mangrove $A$. marina dan melakukan pengujian potensi aktivitas enzim ekstraseluler dari isolat bakteri endofit. Hasil penelitian dipaparkan secara deskriptif eksploratif berdasarkan tahapantahapan penelitian yang dilakukan.

\section{Pengambilan Sampel}

Sampel daun diambil dari tumbuhan mangrove A. marina di Kelurahan Molas, Kecamatan Bunaken, Kota Manado, kemudian dimasukkan dalam kantong plastik dan disimpan dalam cool box. Selanjutnya sampel langsung dibawa ke Laboratoriun Biologi Lanjut (Mikrobiologi) Jurusan Biologi Fakultas Matematika dan Ilmu Pengetahuan Alam Universitas Sam Ratulangi Manado.

\section{Isolasi Bakteri Endofit}

Daun yang digunakan sebagai sampel dicuci bersih dengan air mengalir dan disterilisasi permukaan menggunakan Natrium Hipoklorit selama 2 menit, alkohol
$70 \%$ selama 2 menit, dan dibilas dengan air laut steril sebanyak 3 kali untuk menghilangkan kotoran, maupun organisme epifit yang menempel pada permukaannya. Sampel kemudian dikeringkan di atas tisu steril. Sebanyak $10 \mathrm{gr}$ daun dipotong-potong sampai halus, kemudian dimasukkan ke dalam $90 \mathrm{~mL} \mathrm{NaCl} 0,9 \%$, dilakukan secara aseptik. Isolasi bakteri endofit diawali dengan pengenceran berseri $10^{-2}-10^{-6}$ dan dilanjutkan dengan metode spread plate (metode cawan sebar) pada media TSA (Tryptic Soy Agar).

Setiap perlakuan dilakukan pengulangan sebanyak tiga kali. Selanjutnya diambil koloni-koloni bakteri yang menampakkan morfologi yang berbeda. Koloni bakteri yang tumbuh dimurnikan dengan metode streak plate pada media Nutrient Agar (NA) untuk diperoleh biakan murni atau isolat tunggal.

\section{Skrinning Bakteri Endofit Penghasil Enzim Ektraseluler}

Uji aktivitas enzim amilase ekstraseluler dilakukan dengan prosedur menurut Bairagi et al. (2002). Kultur cair solat-isolat yang diperoleh dari hasil isolasi diinokulasikan ke paper disc blank yang telah diletakkan pada media yang berisi pepton $5 \mathrm{gr} / \mathrm{L}$, beef extract $3 \mathrm{gr} / \mathrm{L}$, amilum $2 \mathrm{gr} / \mathrm{L}$, dan agar $15 \mathrm{gr} / \mathrm{L}$. Inkubasi pada $30^{\circ} \mathrm{C}$ selama 48 jam. Larutan lugol's $1 \%$ dituang ke atas kultur, adanya aktivitas enzim amilase ditunjukan oleh terbentuknya zona jernih di sekitar paper disc dengan latar belakang biru gelap.

Uji aktivitas enzim protease dilakukan dengan prosedur Bairagi et al. (2002). Kultur cair isolat-isolat yang diperoleh dari hasil isolasi diinokulasikan ke paper disc blank yang telah diletakan pada media Zobell 2216 E (pepton, beef extract, agar, dan air laut steril) yang diperkaya dengan skim milk $(1 \%)$ dan di inkubasi pada $32^{\circ} \mathrm{C}$ selama 15 jam. Aktivitas proteolitik ditunjukkan oleh terbentuknya zona jernih di sekitar paper disc dengan latar belakang putih.

Uji aktivitas gelatinase dilakukan dengan cara menyiapkan bahan media gelatin yaitu 
beef extract $3 \mathrm{gr} / \mathrm{L}$, pepton $5 \mathrm{gr} / \mathrm{L}$, gelatin $120 \mathrm{gr} / \mathrm{L}$. Bakteri yang sudah diinokulasi ke media gelatin disimpan pada suhu ruang selama \pm 3 hari. Setelah ditunggu selama \pm 3-7 hari diamati dengan cara tabung reaksi yang berisi isolat bakteri disimpan dalam lemari es dengan suhu $4^{0} \mathrm{C}$ ( \pm 30 menit). Adanya aktivitas enzim gelatinase ditunjukan dengan masih encernya media yang telah diinokulasi setelah dilakukan proses pembekuan pada $4^{0} \mathrm{C}$.

Uji aktivitas selulase dilakukan dengan medium agar diperkaya CMC (Carboxy Methyl Cellulose). Kultur isolat-isolat yang diperoleh dari hasil isolasi diinokulasikan ke paper disc blank yang telah diletakan pada media Zobell 2216 E diperkaya CMC 1\%. Larutan Congo Red dituang ke atas kultur untuk mengetahui adanya aktivitas selulase, selanjutnya dibilas dengan $\mathrm{NaCl} 1 \mathrm{M}$ selama \pm 15 menit. Adanya aktivitas enzim selulase ditunjukan terbentuknya zona bening di sekitar paper disc.

\section{HASIL DAN PEMBAHASAN}

Sampel yang digunakan sebagai sumber isolat bakteri endofit berasal dari tumbuhan mangrove A. marina di Kelurahan Molas, Kecamatan Bunaken, Kota Manado. Bagian tumbuhan yang digunakan yaitu daun. Daun yang dipilih dalam kondisi segar, berwarna hijau, tidak layu dan tidak ada kerusakan pada daun. Pada penelitian ini sampel daun A. marina terlebih dahulu disterilisasi permukaan. Sterilisasi permukaan sampel daun A. marina dilakukan dengan tujuan agar tidak ada bakteri kontaminan. Berdasarkan penelitian dari Sagita et al. (2017), menyatakan sterilisasi permukaan sangat penting dalam mencari bakteri endofit daun agar tidak terkontaminasi oleh mikroorganisme lain yang bukan endofit. Habibah et al. (2013) menyatakan sterilisasi permukaan harus dilakukan agar memperoleh hasil yang baik karena jika tidak steril maka kultur in vitro tidak dapat diperoleh. Hasil isolasi memperoleh tujuh isolat murni bakteri endofit.

Ketujuh isolat bakteri endofit yang telah dimurnikan dan telah dikarakterisasi kemudian diuji aktivitas enzim ekstraseluler. Enzim yang diproduksi oleh mikroorganisme lalu disekresikan ke dalam media ada sering disebut enzim ekstraseluler (Choi et al. 2005). Uji aktivitas enzim ekstraseluler yang dilakukan yaitu uji aktivitas enzim amilase, protease, selulase, dan gelatinase. Metode yang umum digunakan untuk mendeteksi adanya aktivitas enzim ekstraseluler pada mikroba adalah metode plate assay. Pada uji ini menggunakan medium yang mengandung substrat tertentu dan zat pewarna kromogenik. Analisis kualitatif aktivitas enzim amilase, selulase dan protease dilakukan dengan pengukuran zona bening yang terbentuk di sekitar koloni, sedangkan untuk gelatinase dilihat dengan terurainya substrat pada medium yang tetap cair pada suhu $4^{\circ} \mathrm{C}$.

Hasil uji aktivitas enzim ekstraseluler menunjukan empat isolat positif memiliki potensi menghasilkan enzim amilase, satu isolat positif menghasilkan enzim selulase, enam isolat menghasilkan enzim protease, dan dua isolat memiliki potensi menghasilkan enzim gelatinase. Zona bening yang terbentuk di sekitar paper disc atau isolat menunjukkan isolat bakteri endofit mampu menghasilkan enzim (Gambar 1).

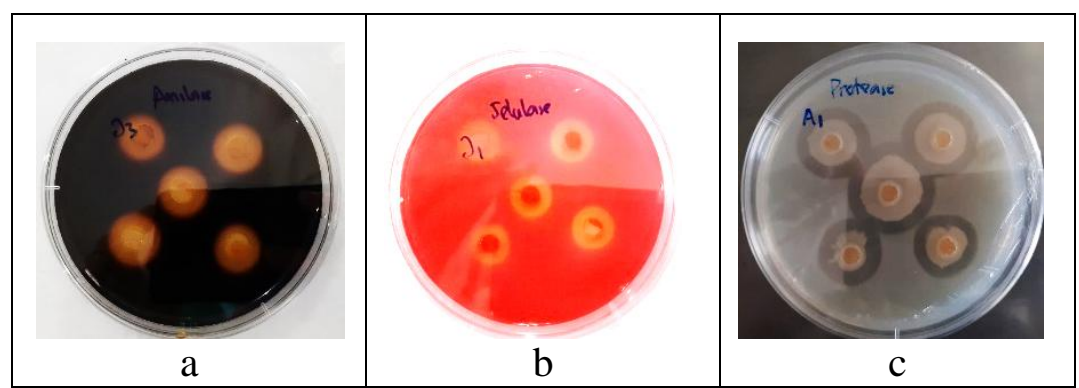

Gambar 1. Hasil uji aktivitas enzim ekstraseluler yang menunjukkan zona bening (a) amilase (b) selulase (c) protease. 
Berdasarkan zona bening yang terbentuk dan nilai indeks rasio dari masing-masing isolat bakteri endofit menunjukkan kemampuan yang bervariasi. Nilai indeks rasio dihitung dari diameter zona bening dibagi diameter kertas atau diameter isolat. Reaksi enzim ekstraseluler menunjukkan reaksi kuat jika rasio enzim ekstraseluler lebih dari sama dengan dua; jika rasio enzim ekstraseluler memiliki nilai antara satu dan dua maka reaksi sedang; dan apabila rasio enzim ekstraseluler kurang dari sama dengan satu maka reaksi lemah (Choi et al. 2005). Kurniawan (2017) menyatakan bakteri yang membentuk zona bening dan diameter isolat diukur dengan menggunakan nilai indeks sehingga dapat mengetahui isolat dengan indeks rasio tertinggi merupakan isolat yang potensial untuk dioptimasi lebih lanjut.

\section{Aktivitas Enzim Amilase}

Hasil uji aktivitas enzim amilase dari ketujuh isolat bakteri endofit, terdapat empat isolat yaitu isolat $\mathrm{B}$, I, J dan $\mathrm{K}$ yang menunjukkan hasil positif dengan ditandai adanya zona bening disekitar paper disc pada media agar selektif amilum. Dari keempat isolat bakteri endofit, perbedaan ukuran zona bening menunjukkan adanya perbedaan kemampuan menghasilkan enzim amilase (Tabel 1).

Tabel 1. Diameter isolat dan zona bening pada uji aktivitas enzim amilase dari isolat bakteri endofit

\begin{tabular}{cccc}
\hline \multirow{2}{*}{$\begin{array}{c}\text { Kode } \\
\text { Isolat }\end{array}$} & \multicolumn{2}{c}{ Rataan \pm Standar Deviasi } & \multirow{2}{*}{ Rasio indeks } \\
\cline { 2 - 3 } & Diameter Isolat & Diameter Zona Bening & \\
\hline A & $0,92 \pm 0,08$ & - & - \\
B & $0,75 \pm 0,05$ & $1,08 \pm 0,13$ & 1,44 \\
C & - & - & - \\
I & $0,78 \pm 0,04$ & $1,12 \pm 0,08$ & 1,44 \\
J & $0,79 \pm 0,02$ & $1,76 \pm 0,09$ & 2,23 \\
K & $1,16 \pm 0,09$ & $2,1 \pm 0,34$ & 1,81 \\
O & $0,72 \pm 0,04$ & - & - \\
\hline
\end{tabular}

Hasil penelitian menunjukkan aktivitas enzim yang diukur berdasarkan nilai indeks rasio yang tertinggi dihasilkan oleh isolat $\mathrm{J}$ dengan nilai rasio 2,23 (Gambar 1a). Hasil pengukuran menunjukkan potensi isolat kode J termasuk kategori kuat. Semakin tinggi indeks rasio maka semakin besar pula potensi isolat bakteri endofit dalam menghasilkan aktivitas enzim amilase pada media.

Zona bening yang terbentuk di sekitar isolat menunjukkan adanya aktivitas isolat amilolitik, yaitu kemampuan isolat dalam menghidrolisis media selektif yang terdapat pada medium pertumbuhan dengan menghasilkan amilase (Asadullah, 2014). Enzim amilase bekerja dengan memecah amilum menjadi senyawa sederhana. Seperti pernyataan Pricilia et al. (2018), besarnya zona bening yang terbentuk di sekitar paper disc yang telah terkandung isolat endofit menandakan banyaknya glukosa yang dihasilkan dari reaksi hidrolisis pati oleh amilase.

\section{Uji Aktivitas Enzim Selulase}

Uji aktivitas enzim selulase dari ketujuh isolat bakteri endofit memperoleh satu isolat yang menunjukkan hasil positif (Tabel 2) dengan ditandai adanya zona bening di sekitar paper disc pada media agar selektif CMC 1\%. Substrat CMC merupakan substrat murni yang mudah dihidrolisis oleh enzim. Bakteri yang mampu memproduksi selulase dapat dilihat dengan menambahkan larutan reagen Congo Red.

Menurut Anand et al. (2009), Congo Red akan berikatan secara spesifik dengan polisakarida yang memiliki ikatan $\beta-1,4$ glikosida, polisakarida yang terkandung dalam media uji adalah CMC. Warna merah menunjukkan sisa selulosa yang tidak terhidrolisis sehingga terjadi pembentukan selulosa-Congo Red. Zona bening yang 
terbentuk dapat dilihat dengan jelas melalui pencucian menggunakan $\mathrm{NaCl} 1 \mathrm{M}$. Zona bening yang terbentuk menunjukkan enzim selulase sangat aktif memecah selulosa seperti CMC menjadi senyawa-senyawa yang lebih sederhana seperti glukosa. Fatichah (2011) menyatakan perombakan CMC oleh enzim selulase memutuskan turunan selulosa seperti CMC menghasilkan selodekstrin, selobiosa, dan glukosa.

Pada penelitian ini, dari ketujuh isolat endofit yang diuji hanya satu isolat yang berhasil menghidrolisis media CMC atau positif, yaitu kode isolat $\mathrm{J}$ (Gambar 1b). Perbedaan indeks rasio aktivitas enzim selulase ini karena masing-masing isolat mempunyai potensi yang berbeda dalam menguraikan substrat dalam media tersebut. Zona bening yang terbentuk di sekitar isolat disebabkan oleh isolat mampu menghasilkan enzim selulase yang menghidrolisis selulosa menjadi glukosa.

Tabel 2. Diameter isolat dan zona bening pada uji aktivitas enzim selulase dari isolat bakteri endofit

\begin{tabular}{cccc}
\hline \multirow{2}{*}{$\begin{array}{c}\text { Kode } \\
\text { Isolat }\end{array}$} & \multicolumn{2}{c}{ Rataan \pm Standar Deviasi } & \multirow{2}{*}{ Rasio indeks } \\
\cline { 2 - 3 } A & Diameter Isolat & Diameter Zona Bening & - \\
B & $0,98 \pm 0,09$ & - & - \\
$\mathrm{C}$ & $0,72 \pm 0,04$ & - & - \\
$\mathrm{I}$ & - & - & - \\
$\mathrm{J}$ & $0,92 \pm 0,11$ & - & 1,92 \\
$\mathrm{~K}$ & $0,74 \pm 0,05$ & $1,42 \pm 0,08$ & - \\
$\mathrm{O}$ & $1,5 \pm 0,46$ & - & - \\
\hline
\end{tabular}

\section{Uji Aktivitas Enzim Protease}

Hasil uji aktivitas enzim protease yaitu dari ketujuh isolat bakteri endofit menunjukkan hanya satu isolat yang negatif atau tidak berpotensi menghasilkan enzim protease. Dari hasil yang diperoleh isolat bakteri endofit yang menghasilkan enzim protease lebih banyak dibandingkan enzim yang lain. Diameter zona bening pada uji aktivitas enzim protease berkisar antara 1,41 $-2,5 \mathrm{~cm}$, dengan kisaran rasio indeks antara 1,47 sampai 1,81 (Tabel 3). Perbedaan nilai indeks rasio dari zona bening yang ada menunjukkan variasi kemampuan menghidrolisis substrat dari masing-masing isolat bakteri endofit.

Isolat bakteri endofit yang positif ditandai dengan adanya zona bening di sekitar isolat pada media skim milk. Zona bening terbentuk di sekitar koloni menandakan bahwa bakteri mampu menghidrolisis substrat (Gambar 1c). Soeka dan Sulistiani (2017) menyatakan bahwa terbentuknya zona bening yang dihasilkan oleh bakteri uji berarti bakteri mampu menghasilkan enzim protease ekstraseluler. Berdasarkan hasil yang diperoleh, isolat bakteri endofit yang memiliki aktivitas enzim protease tertinggi yaitu isolat $\mathrm{B}$ dengan nilai indeks rasio yaitu 1,81. Produksi enzim protease dipengaruhi oleh faktor waktu produksi enzim. Semakin cepat pertumbuhan bakteri yang memiliki kemampuan menghasilkan enzim, maka akan semakin besar zona bening terbentuk. Pertumbuhan bakteri yang sangat cepat mempengaruhi besarnya zona bening. Berdasarkan penelitian Pricillia et al. (2018), menyatakan besarnya zona bening yang terbentuk di sekitar isolat menunjukkan banyaknya produk yang dihasilkan dari hidrolisis protein oleh protease dan terjadinya pemutusan ikatan peptida pada protein oleh protease menjadi unit peptida yang lebih kecil, hidrolisis sempurna dari protein akan menghasilkan asam amino. Abdul (2009) menyatakan bahwa enzim protease mampu memecah protein kasein yang terdapat pada susu skim menjadi peptida-peptida yang lebih sederhana dan asam amino. 
Tabel 3. Diameter isolat dan zona bening pada uji aktivitas enzim protease dari isolat bakteri endofit

\begin{tabular}{cccc}
\hline \multirow{2}{*}{$\begin{array}{c}\text { Kode } \\
\text { Isolat }\end{array}$} & \multicolumn{2}{c}{ Rataan \pm Standar Deviasi } & \multirow{2}{*}{ Rasio indeks } \\
\cline { 2 - 3 } & Diameter Isolat & Diameter Zona Bening & \\
\hline A & $1,68 \pm 0,31$ & $2,5 \pm 0,354$ & 1,49 \\
B & $0,78 \pm 0,04$ & $1,41 \pm 0,055$ & 1,81 \\
C & - & - & - \\
I & $0,89 \pm 0,11$ & $1,54 \pm 0,152$ & 1,73 \\
J & $1,36 \pm 0,13$ & $2,04 \pm 0,18$ & 1,50 \\
K & $1,17 \pm 0,08$ & $1,72 \pm 0,084$ & 1,47 \\
O & $1,36 \pm 0,36$ & $2,14 \pm 0,371$ & 1,57 \\
\hline
\end{tabular}

$\underline{\text { Tabel 4. Uji aktivitas enzim gelatinase dari isolat bakteri endofit }}$

\begin{tabular}{ccc}
\hline \multirow{2}{*}{ Kode Isolat } & \multicolumn{2}{c}{ Aktivitas Enzim Gelatinase } \\
\cline { 2 - 3 } & Keruh & Cair $\left(4^{\circ} \mathrm{C}\right.$ selama 30 menit $)$ \\
\hline A & + & + \\
B & - & - \\
C & - & - \\
I & - & - \\
J & + & + \\
K & - & - \\
O & - & - \\
\hline
\end{tabular}

Keterangan: Tanda (+) positif: berpotensi memiliki aktivitas enzim gelatinase Tanda (-) negatif: tidak memiliki aktivitas enzim gelatinase

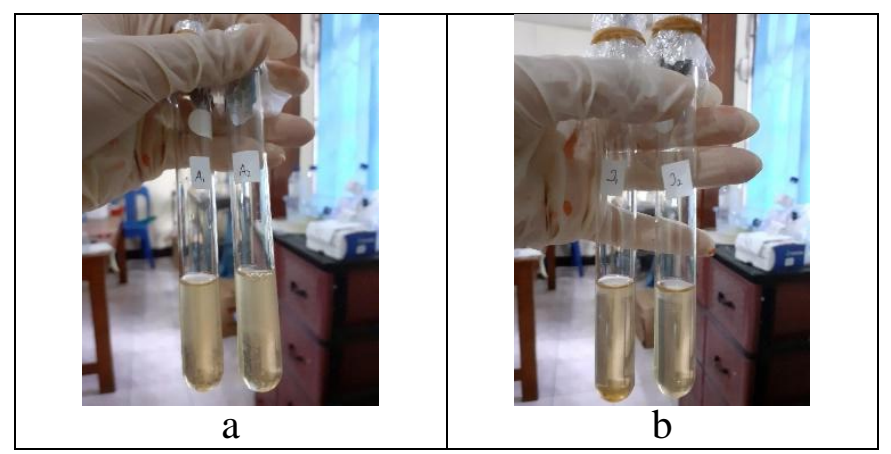

Gambar 2. Hasil uji aktivitas enzim gelatinase menghidrolisis media gelatin ditandai dengan keruh dan cairnya media pada suhu $4^{\circ} \mathrm{C}$ (a) isolat $\mathrm{A}$, (b) isolat $\mathrm{J}$.

\section{Uji Aktivitas Enzim Gelatinase}

Hasil uji aktivitas enzim gelatinase dari isolat bakteri endofit menunjukkan dua isolat mampu menghasilkan enzim gelatinase atau positif melakukan aktivitas enzim gelatinase (Tabel 4). Uji gelatinase dilakukan dengan menginokulasikan isolat bakteri endofit pada media skrining gelatinase yang mengandung substrat. Apabila isolat bakteri endofit positif gelatinase maka media gelatin akan tetap cair pada suhu $4^{\circ} \mathrm{C}$ selama 30 menit. Menurut Nursyam dan Prihanto (2018), penghasil gelatin terbaik yaitu ditandai dengan semakin encernya media setelah didinginkan.

Berdasarkan hasil yang tertera pada Tabel 4, menunjukkan hanya dua isolat yang berhasil melakukan atau menghasilkan hidrolisis gelatin yaitu isolat endofit kode A dan J (Gambar 2). Penghasil gelatinase ditandai dengan perubahan warna media dan cairnya media walaupun dibekukan. Perubahan warna media yang menjadi keruh karena adanya pertumbuhan isolat bakteri pada media, serta cairnya media menunjukkan aktivitas bakteri yang merombak gelatin yang menjadi substrat di 
medium (Prihanto et al. 2018). Penelitian dari Nursyam dan Prihanto (2018) memperoleh hasil aktivitas enzim gelatinase pada isolat bakteri endofit yang terdapat pada daun memiliki kategori tinggi ditandai dengan cairnya media gelatin.

Enzim gelatinase merupakan enzim yang berperan penting pada sektor indutri pangan dan non pangan. Gelatin pada pangan berfungsi sebagai pengatur keseimbangan, pengembang, pembentuk gel, pengental, dan sebagainya. Menurut Smith dan Goodner (1958), bakteri penghasil gelatinase dapat menghidrolisis gelatin menjadi senyawa yang lebih sederhana seperti asam amino. Sejalan dengan Foox dan Zilberman (2015) menyatakan enzim gelatinase pada saat ini mendapat banyak perhatian sebagai target pengembangan obat karena potensinya sebagai penghantar obat-obatan dan bioaktif. Potensi gelatinase untuk menghasilkan produk hidrolisat gelatin, meningkatkan permintaan enzim ini.

\section{KESIMPULAN}

Hasil penelitian memperoleh tujuh isolat bakteri endofit tumbuhan A. marina, sebanyak empat isolat menghasilkan enzim amilase, enam isolat menghasilkan protease, satu isolat menghasilkan selulase dan dua isolat menghasilkan gelatinase.

\section{DAFTAR PUSTAKA}

Abdul (2009) Karakterisasi Sifat Biokimia Hasil Penapisan Isolat Bakteri Kitinolitik. Skripsi. Jurusan Biologi Fmipa Universitas Haluoleo. Haluoleo.

Anand, Vennison, Sankar, Prabhu, Vasan, Raghuraman, Geoffrey, Vendan (2009) Isolation and Characterization of Bacteria from the Gut Of Bombyx mori that Degrade Cellulose, Xylan, Pectin and Starch and Their Impact on Digestion. J of Insect Science. 10(107): $1-20$.

Asadullah M (2014) Isolasi Bakteri Amilolitik dari Bekatul dan Uji Kemampuan Untuk Produksi Enzim Amilase Kasar Pada Berbagai Jenis
Media Produksi. Skripsi. Fakultas Sains dan Teknologi UIN. Malang.

Bairagi A, Ghosh KS, Sen SK (2002) Enzyme Producing Bacterial Flora from Fish Digestive Tracts. Aquaculture International 10(2): 109-121.

Cappuccino JG, Sherman N (2005) Microbiology A Laboratory Manual sevent edition. State University, Rockland Community College, New York.

Choi, YW, Hodgkiss, IJ, Hyde, KD (2005) Enzyme Production By Endophyte Of Brucea javanica. Jurnal Of Agriculture Teknologi 1: 55-66.

Fatichah NFY (2011) Potensi Bakteri Endofit Sebagai Penghasil Enzim Kitinase, Protease dan Selulase Secara In Vitro. Skripsi. Universitas Islam Negeri Malang. Malang.

Foox M, Zilberman M (2015) Drug delivery from gelatin-based systems. Expert Opinion on Drug Delivery. 12(9): 15471563

Habibah NA, Sumadi, Ambar A (2013) Optimasi Sterilisasi Permukaan Daun dan Eliminasi Endofit pada Burahol. Biosaintifika. 5 (2): 95-99.

Hallman J, Quadt-Hallmann A, Mahaffee WF, Kloepper JW (1997) Bacterial endophytes in agricultural crops. J. Microbiol. 43: 895-914.

Melliawati R, Rohmattusolihat, Nuryati, Rahmani N, Yopi (2016) Seleksi Dan Identifikasi Bakteri Endofit Potensial Penghasil Enzim Protease dari Taman Nasional Gunung Halimun. Bioprodal Industri 7(2): 73-82.

Nursyam H, Prihanto A (2018) Identifikasi Molekuler Bakteri Endofit Mangrove Rizhopora mucronata Penghasil Gelatinase (MMP2). JPHPI. 21(1): 143147.

Pricilia S, Astuti W, Marliana E (2018) Skrining Bakteri Endofit Penghasil Amilase, Lipase Dan Protease Dari Daun Macaranga hullettii King ex Hook.f. Jurnal Atomik 3(2) : 102-105.

Prihanto AA, Timur H, Jaziri A, Nurdiani R, Pradarameswari K (2018) Isolasi dan 
Identifikasi Bakteri Endofit Mangrove Soneratia alba Penghasil Enzim Gelatinase dari Pantai Sendang Biru, Malang, Jawa Timur. Indoneisan Journal of Halal 1(1) 31-42.

Sagita D, Suharti N, Azizah N (2017) Isolasi Bakteri Endofit Dari Daun Sirih (Piper betle L.) Sebagai Antibakteri Terhadap Escherichia coli dan Staphylococcus aureus. Jurnal Iptek Terapan 11(1): 6574.

Saprudin, Halidah (2012) Potensi dan nilai manfaat langsung hutan mangrove di
Kabupaten Sinjai Sulsel. Jurnal Penelitian Hutan dan Konservasi Alam 9(3) : 213-219.

Smith HL, Goodner K (1958) Detection of Bacterial Gelatinases by Gelatine-Agar Plate Methods. Journal of Bacteriology 662-665

Soeka YS, Sulistiani S (2017) Karakterisasi Enzim Protease dari Bakteri Stenotrophomonas sp. Asal Gunung Bromo, Jawa Timur. Jurnal Ilmu-ilmu Hayati 16(2): 203-211. 